\title{
The Development of Local Wisdom-Based CAI Media for Mathematics Learning at Elementary School
}

\author{
Desy Dwi Riana \\ FKIP, Universitas Islam Balitar, Blitar, Indonesia \\ e-mail: rianadesy12@gmail.com
}

Ida Putriani

FKIP, Universitas Islam Balitar, Blitar, Indonesia e-mail:idaputri918@gmail.com

\section{A R T I C L E I N F O \\ Article history: \\ 25 December 2020 \\ Received in revised form \\ 01 January 2021 \\ Accepted 25 January 2021 \\ Available online 03 Pebruari \\ 2021 \\ Kata Kunci: \\ Matematika, Kearifan Lokal, \\ Kontekstual \\ Keywords: \\ Mathematics, Local Wisdom, \\ Contextual}

\begin{abstract}
A B S T R A K
Modernisasi dalam pendidikan menuntut pembaharuan proses pembelajaran. Perlu adanya upaya untuk menciptakan pembelajaran berbasis IT yang interaktif dan menyenangkan. Kemudian, siswa kelas empat sudah mahir dan bersemangat untuk mengoperasikan komputer, tetapi guru belum sepenuhnya mengintegrasikan komputer ke dalam proses pembelajaran matematika. Untuk itu diperlukan media pembelajaran berbasis komputer dengan konteks nyata kearifan lokal. Tujuan penelitian ini adalah (1) menghasilkan media pembelajaran berbasis IT yang valid dan menarik (2) menciptakan pembelajaran matematika kontekstual yang terintegrasi dengan kearifan lokal. Ini merupakan penelitian pengembangan yang dilakukan dengan menggunakan model ADDIE (Analyze-Design-Develop-Implement-Evaluate). Subjek penelitian ini adalah siswa kelas empat. Teknik pengumpulan data menggunakan observasi, wawancara, dan angket. Data dianalisis secara kuantitatif dan kualitatif. Media CAI dibuat dengan adobeflash yang berisi materi, soal latihan, evaluasi, dan dua permainan menarik. Berdasarkan hasil penilaian ahli media, media CAI dinyatakan layak dengan persentase 83,9\% sedangkan dari penilaian ahli materi diperoleh 90,6\% dalam kategori sangat layak. Dapat disimpulkan bahwa media CAI yang dikembangkan dapat diterapkan
\end{abstract} dalam proses pembelajaran. Implikasi dari penelitian ini adalah adanya media pembelajaran ini dapat membantu siswa dalam memahami materi pelajaran dan mewujudkan pembelajaran berbasis IT.

\begin{abstract}
A B S T R A C T
The modernization in education demands a renewal of the learning process. There needs to be an effort to create interactive and fun IT-based learning. Then, the fourth grade students are proficient and excited to operate computers, but the teacher has not fully integrated computers into the mathematics learning process. So, it is necessary to have computer-based learning media with a real context of local local wisdom. The objectives of this study are (1) to produce valid and interesting IT-based learning media (2) to create contextual mathematics learning that is integrated with local wisdom. This is development research which carried out using the ADDIE (Analyze-Design-Develop-Implement-Evaluate) model. The subjects of this study were fourth grade students. The techniques used to collect data were observation, interviews, and questionnaires. Data were analyzed quantitatively and qualitatively. CAI media is made with adobeflash which contains material, practice questions, evaluation, and two interesting games. Based on the results of the media expert's assessment, CAI media was considered feasible with a percentage of $83.9 \%$, while from the material expert's assessment, it was obtained $90.6 \%$ in the very feasible category. It can be concluded that the developed CAI media can be applied in the learning process. The implication of this research is that the existence of this learning media can help students understand the subject matter and realize IT-based learning.
\end{abstract}

\section{Introduction}

Modernization in the education is exposed with the presence of computers which support learning to make it more attractive. Indonesia must develop human resources who capable to take advantage of the developments in science and technology. It aims to be used for learning, such as computer-based learning media (Bardi \& Jailani, 2015; Haviluddin, 2010). The characteristic of computers with user interfaces makes students more enthusiastic about learning (Darwin, Ridwan, \& Ahyanuardi, 2020; Herayanti \& Habibi, 2017). Learning media has a function as a carrier of information that can make it easier for students to learn. In addition, learning media which are packaged attractively also make students motivated and interested in learning so it can increase student interest in learning (Rahmi, Budiman, \& Widyaningrum, 2019; Tafonao, 2018). Computer-based learning media is needed in this era. 
The problem that occurs today is that there are still many teachers who do not use technology as a learning media (Kuswanto \& Walusfa, 2017; Wulandari, Sudatha, \& Simamora, 2020). But actually the case is that there are many students who are able to operate technology in their daily lives. A preliminary study conducted at Alam Al Ghifari Elementary School in Blitar which shows that fourth grade students are able to operate computers and often use them in their daily life. This shows that students understand technology and have an interest in operating computers. The students revealed that they use computers to play games because computer-based games are considered fun. On the other hand, $90 \%$ of students have difficulty learning mathematics because teachers rarely use interesting learning media. This condition is the basis for learning with computer-based media. However, seeing the practice of learning in schools, teachers still less benefit because the use of computer-based media requires careful preparation both at pre-learning and during learning. Therefore it is necessary to follow up with the use of CAI media which is easy to operate and fun.

Table 1. Results of preliminary observations of students' interest

\begin{tabular}{llcc}
\hline \multirow{2}{*}{ No } & \multirow{2}{*}{ Statements } & \multicolumn{2}{c}{ Percentage of Answers } \\
\cline { 3 - 3 } & & Yes & No \\
\hline 1 & Mathematics is a difficult subject & $90 \%$ & $10 \%$ \\
2 & The teacher always uses instructional media in teaching mathematics & $20 \%$ & $80 \%$ \\
3 & The teacher adopts interesting instructional media & $30 \%$ & $70 \%$ \\
4 & The teacher frequently uses computer-based media & $0 \%$ & $100 \%$ \\
5 & I am interested in learning by using computer-based multimedia & $90 \%$ & $10 \%$ \\
6 & Fractions are tough material & $30 \%$ & $70 \%$ \\
\hline
\end{tabular}

Besides being fun, the learning process must also be done as a miniature of the real world. This means that each material presented uses a context that is close to the daily lives of students (Nilasari, Djatmika, \& Santoso, 2016; Purnamawati, Suardika, \& Manuaba, 2014). The context is that in the form of objects which can be imagined/manifest in the minds of students, so that they are easy to understand. However, the practice of learning mathematics so far has not been fully adapted to the knowledge and culture of students. This creates a paradigm of mathematics as a difficult subject (Prawitaningrum \& Endarini, 2019; Widodo \& Kartikasari, 2017). Therefore, it is necessary to develop computer-based mathematics learning media related to student life in the form of local wisdom. Internalization of local wisdom in learning encourages the delivery of subject matter to be more concrete in the student's minds, and becomes a media for passing on a regional noble values to the future generations as recommended by UNESCO.

One of the computer-based learning media that suits to the characteristics of elementary school students is CAI (Computer Assisted Intruction). The latest technology media or microprocessor-based media have several choices of media types to help the learning process, namely, interactive, computer-assisted instruction (CAI) (Nurfitriana, 2015). CAI is an integrated technology development that combines several components, including images, video, audio, and animation, all of which are packaged into one. CAI can be used for classical learning using projectors or given to each student as individual learning media both at school and at home (Marwiyah, Rusijono, \& Arianto, 2019; Purwani, 2015). CAI can support learning but is not the main messenger of subject matter. CAI media can also be modified into games for the learning process.

The research which conducted by Sagala, Mesran, Sutiksno, Yuhandri, \& Suginam (2017) developing web-based CAI for learning Indonesian traditional clothing. This media contains material, questions, simulations, and games. It is equipped with multimedia and web. The web contains a description of the material presented in sequence. The difference in the product to be developed lies in its shape. This research focuses on developing multimedia flash where the material presented in it using voice stories to make it easier to understand by elementary school students. The second research conducted by Hanida, Iriani, \& Arthur (2015) stated that the CAI media developed contained material, practice questions, evaluation questions, developer profiles, and references. Media is feasible with an average score of material validation of $86 \%$, and a score of media validation of $81 \%$. Based on the results of media validation, the CAI media was declared feasible. Furthermore, in the experiment using 2 classes, the results of the increase in learning outcomes were $19.21 \%$ in the experimental class and $13.3 \%$ in the control class. The difference with the current study is on the menu; the product to be designed is given an additional game menu that is still related to the material so that it can be a fun closing lesson as well as a context amplifier.

This research aimed to produce valid and attractive IT-based learning media and to create contextual mathematics learning which is integrated with the local wisdom. This research is expected to produce multimedia learning CAI that combines material with elements of local culture, so that it is more concrete for 
students. Furthermore, it is planned that the media has a high level of readability, so that it is easy to operate and can be used effectively in learning mathematics.

\section{Method}

This development research was conducted using the ADDIE (Analyze-Design-Develop-implementevaluation) model. Data collection was carried out on 5-10 fourth grade students in Blitar who were taken randomly from one of the representative schools. The limitation on the number of subjects was carried out due to the application of social distancing learning during the Covid-19 pandemic.

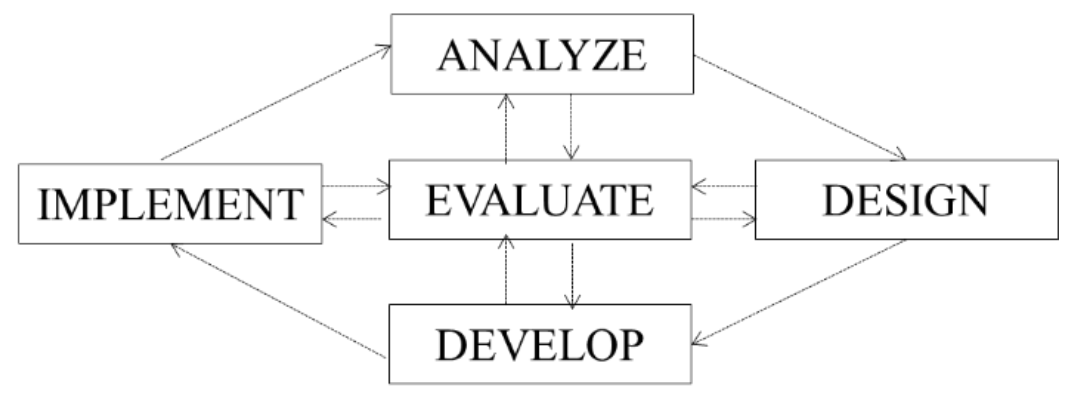

Figure 1. ADDIE Development Model

The research stages are as follows: First, analysis, which includes competency analysis that must be mastered by students (affective, cognitive, psychomotor), analysis of student characteristics (learning styles and interests), and material analysis according to basic competencies, indicators, and learning objectives. Second, design, which includes determining the methods and learning strategies used in CAI-based learning, and the design of supporting resources (relevant teaching materials, conducive classroom conditions). Third, Develop, which includes collecting reference material and illustration images to be included in CAI media, as well as making flowcharts and storyboards. A flowchart is a diagram that provides an overview of the flow from one slide to the next. Meanwhile, the storyboard describes the icon of each slide clearly and in detail. At the Develop stage, the researcher developed the CAI media based on the flowcharts and storyboards that had been made and finally the CAI media was validated to the experts. Fourth, Implement, which includes testing the products that have been made. This product trial aims to determine the effectiveness and attractiveness of the designed CAI media. The last stage is Evaluate which is done by assessing the learning media based on input, suggestions, and corrections obtained from the validation process and field trials. The results of the assessment are used to improve the CAI media.

The data in this research were collected using several methods. First, interviews were conducted in a preliminary study to determine students' interest in computer-based learning and to obtain direct information from mathematics teachers about problems in learning mathematics. Interviews were also conducted after product trials to find out more about student responses. While the questionnaire was given to material experts and media experts to get criticism and suggestions for improving CAI media related to design, sound, animation, and content. In addition, questionnaires were also given to students after product trials to find out their responses to CAI media. The data obtained were then analyzed. Data in the form of criticism and suggestions obtained from the validator and the results of the interviews were analyzed qualitatively, while the scores of the validity questionnaire and the readability questionnaire were analyzed quantitatively

\section{Result and Discussion}

This research begins by analyzing the competence and interests of students by conducting interviews with teachers and giving questionnaires to students. The results of interviews with teachers (Table 2) indicate that the school has facilitated computer-based learning. The school provides LCDs for learning in classical classrooms as well as comprehensive computer laboratories for individual learning. However, the teacher stated that the portion of learning using computer-based multimedia was still not dominant, considering that learning using computers required more preparation. Teachers should spend more time compiling lesson materials in the form of digital files that are attractive and easy to understand. 
Table 2. The result of interview with the fourth grade's teacher

\begin{tabular}{|c|c|}
\hline Questions & Answers \\
\hline $\begin{array}{l}\text { Does mathematics learning always use } \\
\text { computers? }\end{array}$ & Not \\
\hline $\begin{array}{l}\text { Are the school facilities adequate for the } \\
\text { implementation of computer-based learning? }\end{array}$ & Adequate \\
\hline $\begin{array}{l}\text { What are the obstacles for the teacher in } \\
\text { creating computer-based media? }\end{array}$ & Time \\
\hline $\begin{array}{l}\text { Are students interested in computer-based } \\
\text { media? }\end{array}$ & Interested \\
\hline $\begin{array}{l}\text { How is the students' enthusiasm in learning } \\
\text { mathematics? }\end{array}$ & $\begin{array}{l}\text { The students are quite enthusiastic when using interesting } \\
\text { media in learning. If they do not use media, they are inclined } \\
\text { to get bored easily }\end{array}$ \\
\hline $\begin{array}{l}\text { What are the teacher's suggestions if } \\
\text { computer-based media is developed for grade } \\
\text { IV students? }\end{array}$ & $\begin{array}{l}\text { It is suggested to create media that is easy to operate, } \\
\text { interesting, and related to the students' daily lives. }\end{array}$ \\
\hline
\end{tabular}

The results of the interview showed that the teacher had insufficient time to make learning media. This was due to the countless teacher administrative duties. These demands are in line with the assessment rules in the 2013 curriculum where the assessment of the competence of students is carried out on each basic competency. In addition, the teacher should write an attitude assessment journal every day and create follow-up plans for struggling students. This is of course very unfortunate because the school has adequate facilities to support the implementation of computer-based learning such as CAI. The school has a computer laboratory. In addition, there is an LCD in the classroom that can be used by teachers for computer-based classical learning.

On the other hand, based on the results of the questionnaire (Table 3), students expressed their interest in learning using computer-based media because all students of Alam Al Ghifari Elementary School were technology literate. In everyday life, students are familiar with computers to play with. In addition, they take part in computer extracurricular activities at school. Responding to these student interests, teachers need to present interactive multimedia learning for individual and group learning, especially in mathematics learning which is considered a challenging subject. Referring to the results of the questionnaire, students had difficulty understanding the material because they did not follow the lesson well. Students are less interested during the learning process, so that the focus of learning is not maximally achieved.

Table 3. The results of the questionnaire about the needs of fourth grade students

\begin{tabular}{lcc}
\hline \multicolumn{1}{c}{ Statements } & \multicolumn{2}{c}{ Percentage of Answers } \\
\cline { 2 - 3 } & Yes & No \\
\hline Mathematics is a difficult subject & $90 \%$ & $10 \%$ \\
The teacher always uses instructional media in teaching mathematics & $20 \%$ & $80 \%$ \\
The teacher adopts interesting instructional media & $30 \%$ & $70 \%$ \\
The teacher frequently uses computer-based media & $0 \%$ & $100 \%$ \\
I am interested in learning by using computer-based multimedia & $90 \%$ & $10 \%$ \\
Fractions are tough material & $30 \%$ & $70 \%$ \\
\hline
\end{tabular}

Furthermore, the researcher conducted a competency analysis that must be mastered by students based on the basic competencies of the 2013 curriculum. The basic competencies explained the concept of fractions using pictures, and the concrete model was translated into three indicators, namely: (1) explaining the concept of fractions as part of the whole (2) explaining the concept of fractions as the division of two numbers and (3) explain the concept of fractions as a comparison. Based on basic competency learning, it is known that fourth grade students must have mastered the concept of fractions. There are three concepts of fractions contained in this multimedia learning, namely fractions as part of the whole, fractions as the division of two numbers, and fractions as comparisons. From the results of the analysis of basic interests and competencies that must be mastered by fourth grade students, multimedia learning was developed with the concept of fraction material presented contextually by combining local wisdom.

After analyzing the potential problems, the next stage is the design stage. At this stage, the researcher designs learning models and methods that will be used when learning using multimedia, and determines the relevant teaching materials used as a source for making fraction material. The source of the teaching materials used is a book entitled Guiding Children's Learning of Mathematics published by John Wiley and Son Inc., and 
written by Steve Leonard M.Kennedy, as well as other books with the title Mathematics for Elementary Teachers, A Contemporary Approach by Musser GL, Burger WF, and Peterson BE. The next stage is to develop the media. Media development is carried out based on the following flowchart (Figure 2)

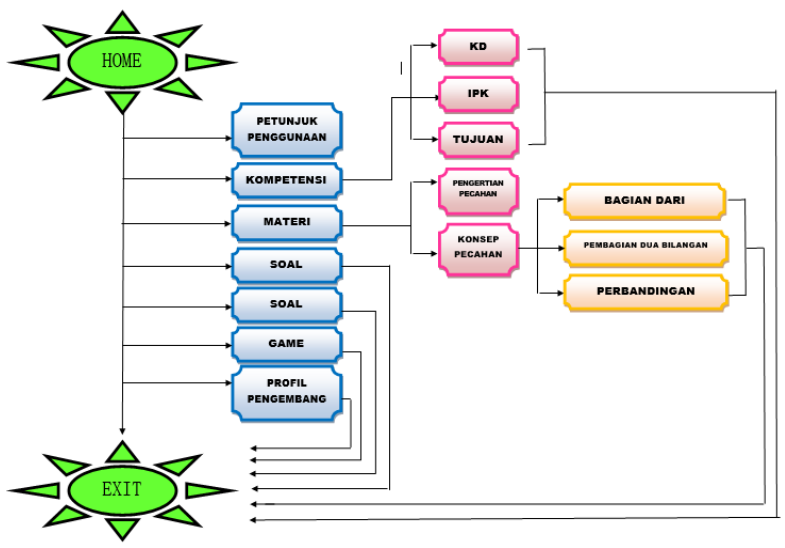

Figure 2. Flowchart media CAI

The media that had been made were then validated by 3 lecturers as media experts and material experts. The validation process aims to obtain an assessment as well as criticism and suggestions for media evaluation. The detailed results of the media validation are presented in Table 3 and Table 4.

Table 3. The results of media validation

\begin{tabular}{|c|c|c|}
\hline \multirow[t]{2}{*}{ No. } & \multirow[t]{2}{*}{ Indicator } & \multirow{2}{*}{$\begin{array}{c}\text { Score } \\
\mathrm{V} 1+\mathrm{V} 2 \\
\end{array}$} \\
\hline & & \\
\hline 1 & The font is readable and and the size is proper & 7 \\
\hline 2 & $\begin{array}{l}\text { The background image matches the material and does not } \\
\text { interfere with the writing }\end{array}$ & 7 \\
\hline 3 & $\begin{array}{l}\text { The characters are in accordance with the characteristics of } \\
\text { elementary school students }\end{array}$ & 7 \\
\hline 4 & $\begin{array}{l}\text { The color composition is attractive and does not interfere } \\
\text { with the view }\end{array}$ & 7 \\
\hline 5 & $\begin{array}{l}\text { The voice of the material explanation is clear and } \\
\text { understandable }\end{array}$ & 8 \\
\hline 6 & The backsound is appropriate and not too harsh & 8 \\
\hline 7 & The software is easy to operate on a computer or PC & 8 \\
\hline 8 & $\begin{array}{l}\text { Instructions for using the media are clear and easy to } \\
\text { understand }\end{array}$ & 6 \\
\hline 9 & The layout of the navigation buttons is appropriate & 6 \\
\hline 10 & The navigation keys are consistent from start to finish & 6 \\
\hline 11 & The media is easy to operate by the students & 6 \\
\hline 12 & The language used is easy to understand & 6 \\
\hline 13 & $\begin{array}{l}\text { The language used is in accordance with the stage of the } \\
\text { students' development }\end{array}$ & 6 \\
\hline 14 & $\begin{array}{l}\text { The language used is in accordance with the structure of } \\
\text { bahasa Indonesia }\end{array}$ & 6 \\
\hline & Total & 94 \\
\hline & Percentage & $83.9 \%$ \\
\hline & Category & Feasible \\
\hline
\end{tabular}

The results of media validation show that the media layout is good. Any suggestions from the validator regarding the media manual; namely arranging menu in a clear order, so that students do not choose menu arbitrarily. The correct menu order is home, basic competencies and indicators, material (part of the whole, comparison, division of two numbers) accompanied by sample questions, evaluation, and games (matching and puzzle). In addition to the menu order, the validator suggested adding a manual for the use of printed media, so 
that students and teachers could understand the use of the media before using it. This is related to the ease of operation of the media which must take precedence. In terms of language, this media uses language in accordance with the stages of student development. Based on the validator's assessment, it can be concluded that this media has an attractive appearance, clear material presentation, easy-to-read writing layout, appropriate characters, and appropriate language. The manual contains an explanation of the media, menus, and display order, descriptions of symbols / icons, and operations on the computer.

Table 4. The results of material validation

\begin{tabular}{llc}
\hline No. & \multicolumn{1}{c}{ Indicators } & Score \\
\hline 1 & Indicators and learning objectives are in accordance with basic & 4 \\
& competence & 4 \\
2 & The material presented is in line with the formulated indicators & 4 \\
3 & The material is consistent with scientific principles & 4 \\
4 & The material is presented coherently from easy to difficult level & 4 \\
5 & The suitability of material with the students' characteristics & 3 \\
6 & The suitability of practice questions with the material & 3 \\
7 & The suitability of evaluation questions with indicators & 3 \\
8 & The suitability of quiz with the material & $\mathbf{2 9}$ \\
\hline & Total & $\mathbf{9 0 . 6 \%}$ \\
\hline & Percentage & Very Feasible
\end{tabular}

The results of material validation indicate that the media developed is very feasible, because it contains indicators and learning objectives that are in accordance with basic competencies. The following is the final design of CAI media for learning mathematics in elementary schools made with the adobeflash program:

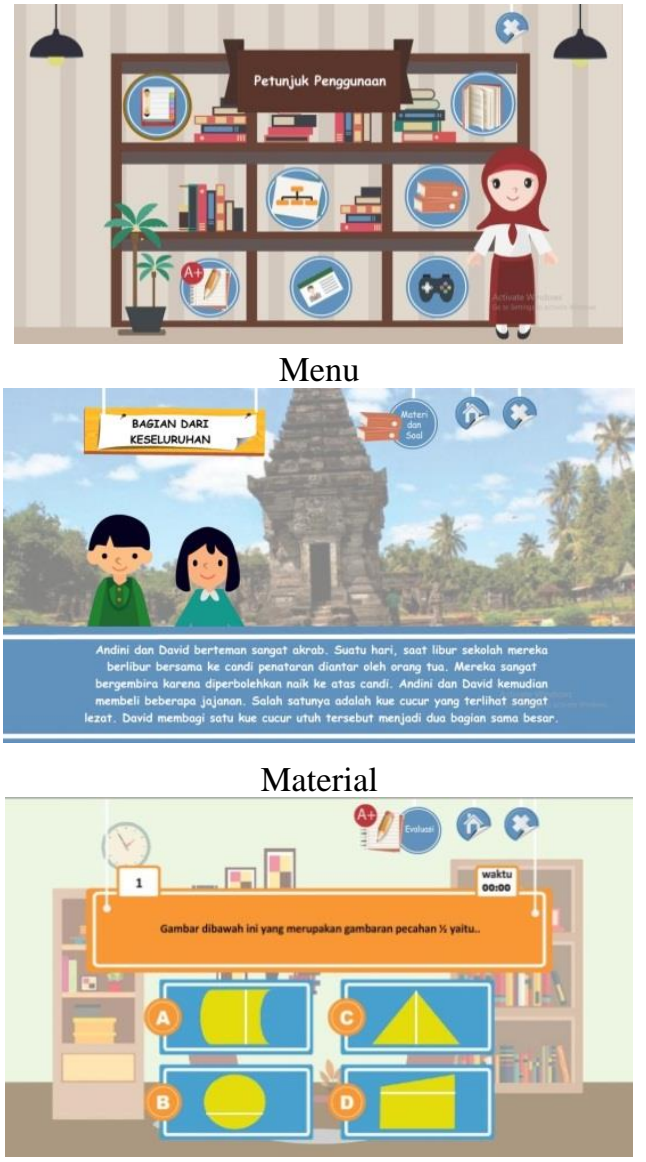

Evaluation

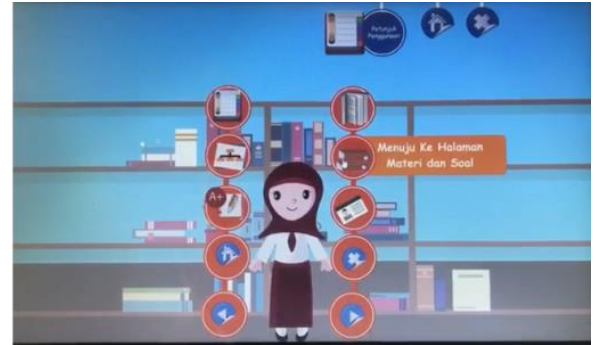

Guideline Button
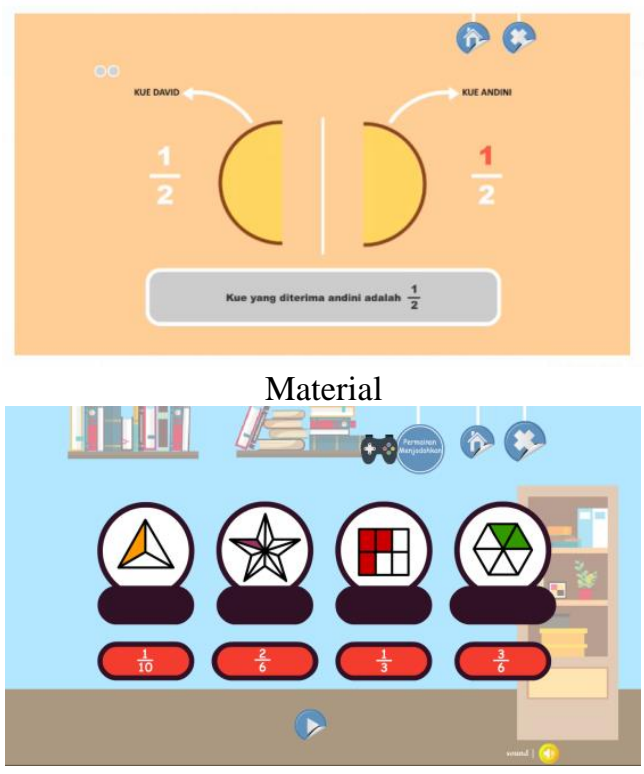

Match Game 
Based on the results of questionnaires given to experts, the advantages of CAI media are assessed as follows: it has an attractive appearance because it presents various types of media at once including audio, visual, and motion. Students will be more interested in various layouts supported by appropriate character animations, clear voices, and easy-to-read material explanations because they are supported by illustrated images. Meanwhile, the weakness of CAI media lies in the absence of a non-digital instruction manual to operate the media. The CAI media developed is feasible to be applied in the learning process due to several factors, namely as follows.

First, the developed CAI media is feasible to apply because the material presented is appropriate, making it easier for students to learn. As stated in the 2013 curriculum, learning indicators must be in accordance with basic competencies (Kurniaman \& Noviana, 2017; Rahmawati, 2018). The basic competencies chosen in this study are fractions that are converted into 3 indicators that must be mastered by fourth grade students. The material presented refers to a credible book, so that its accuracy and integrity can be accounted for. The material is presented from easy to difficult levels, and is conveyed using contextual illustrations. The use of the context of local wisdom is not only to make these objects relevant to students' lives, but also to familiarize students with the surrounding culture. Contextual mathematics learning provides many benefits (Gitriani, Aisah, Hendriana, \& Herdiman, 2018; Khoeriyah \& Mawardi, 2018; Santoso, 2017).

Second, the developed CAI media is feasible to apply because in terms of content there are also practice questions in the CAI media accompanied by explanations of how to answer questions. In addition, there are evaluations that have a true false mark; so, if a student's answer is wrong, they will immediately identify it, and they will be shown the correct answer. Furthermore, at the end of the CAI media there is a game of playing while learning, namely matching numbers and numbers. If the answers do not match, the image will not be able to occupy the desired shape. The validator suggested that there be additional games so that there are several types of games in the CAI media to strengthen students' understanding. To answer this suggestion, the researcher made a puzzle game. Learning while playing is fun for elementary students. Educational games are an effective medium for children to learn difficult subjects such as mathematics (Fauziddin, 2015; Siregar, Wardani, \& Hatika, 2017). Through computer-based media containing games, students will be eager to learn, thus triggering curiosity and enthusiasm in answering each question (Bardi \& Jailani, 2015; Kuswanto \& Walusfa, 2017; Sagala et al., 2017).

Third, the developed CAI media is feasible to apply because the CAI media is easy to use and can attract students in learning. Font selection is appropriate and easy to read. Fonts that are too small and have unusual shapes should be avoided. The selection of the background is in accordance with the material presented, so that synchronization occurs. The background is displayed in a low contrast to make the material more visible. In terms of color, color combinations are made on each slide, so that students don't get bored easily, and use cool colors so they don't interfere with the view. These characters are also in accordance with the characteristics of elementary school students; these characters include students, teachers, and parents. Regarding the sound, the material explanation and background sound are appropriate. His voice sounded clear and loud. Backsound uses upbeat music, so that students don't get sleepy while listening to explanations from the media. The clarity of sound and the flexibility of media operation get the highest score. In addition, the user manual and the explanation of button usability score well. Good media is certainly easy to operate, in accordance with learning objectives, and has an attractive layout (Ayuni, Kusmariyatni, \& Japa, 2017; Rahmi et al., 2019). Meanwhile, what still needs to be improved is the instructions for using the media. Teachers and students will be greatly helped by the existence of non-digital manuals.

Research conducted by Marwiyah et al., (2019) states that Android-based CAI media can be used as a learning medium that supports the teaching and learning process. Research conducted by Hanida et al., (2015) states that the development of interactive multimedia CAI is effectively used in the learning process to improve student learning outcomes. Research conducted by Purwani (2015) states that CAI can help people understand learning material. Based on this research, it can be concluded that CAI media can be used in the learning process. The implication of this research is that the existence of this learning media can help students understand the subject matter and realize IT-based learning.

\section{Conclusion}

The development of CAI media for mathematics learning based on local wisdom has been declared suitable for the learning process. The developed CAI media contains learning indicators that must be mastered, materials, practice questions accompanied by explanations, evaluations along with answer keys, and games, namely drag and drop and puzzles. CAI media has an attractive layout, the right color play, appropriate characters for elementary school students, and uses animation in material explanations, as well as pictures of local wisdom as the context. 


\section{References}

Ayuni, I. A. S., Kusmariyatni, N., \& Japa, I. G. N. (2017). Pengaruh Model Pembelajaran Talking Stick Berbantuan Media Question Box Terhadap Hasil Belajar IPA Kelas V. Journal of Education Technology, 3(1). https://doi.org/http://dx.doi.org/10.23887/jet.v1i3.12503

Bardi, \& Jailani. (2015). Pengembangan Multimedia Berbasis Komputer Untuk Pembelajaran Matematika Bagi Siswa SMA Pendidikan. Jurnal Inovasi Teknologi, 2(1), 49-63. https://doi.org/https://doi.org/10.21831/tp.v2i1.5203

Darwin, Ridwan, \& Ahyanuardi. (2020). Efektivitas Pengembangan Modul Berbasis Konstruktivisme Pada Mata Pelajaran Sistem Komputer Bagi Siswa TKJ Tingkat SMK. Jurnal EDUTECH Universitas Pendidikan Ganesha, 8(1), 147-155. https://doi.org/http://dx.doi.org/10.23887/jeu.v8i1.27259

Fauziddin. (2015). Peningkatan Kemampuan Matematika Anak Usia Dini Melalui Permainan Jam Pintar di Taman Kanak-Kanak Pembina Kec. Bangkinang Kota. Jurnal PAUD Tambusai, 1(1), 49-54. https://doi.org/https://doi.org/10.31004/obsesi.v1i1.55

Gitriani, Aisah, Hendriana, \& Herdiman. (2018). Pengembangan Lembar Kerja Siswa Berbasis Pendekatan Kontekstual pada Materi Lingkaran Untuk Siswa SMP. Jurnal Review Pembelajaran Matematika, 3(1). https://doi.org/https://doi.org/10.15642/jrpm.2018.3.1.40-48

Hanida, E. Y., Iriani, T., \& Arthur, R. (2015). Pengembangan Media Pembelajaran Multimedia Interaktif CAI Pada Mata Pelajaran Mekanika Teknik Kelas X di SMK Negeri 1 Jakarta. Jurnal Pensil: Pendidikan Teknik Sipil, 4(2). https://doi.org/https://doi.org/10.21009/jpensil.v4i2.9879

Haviluddin. (2010). Active Learning berbasis Teknologi Informasi (ICT). Jurnal Ilmiah Ilmu Komputer, 5(3). https://doi.org/http://dx.doi.org/10.30872/jim.v5i3.64.

Herayanti, L., \& Habibi, H. (2017). Model Pembelajaran Berbasis Masalah Berbantuan Simulasi Komputer untuk Meningkatkan Keterampilan Berpikir Kritis Calon Guru Fisika. Jurnal Pendidikan Fisika Dan Teknologi, 1(1), 61-66. https://doi.org/10.29303/jpft.v1i1.236

Khoeriyah, N., \& Mawardi, M. (2018). Penerapan Desain Pembelajaran Tematik Integratif Alternatif Berbasis Kearifan Lokal untuk Meningkatkan Hasil dan Kebermaknaan Belajar. Mimbar Sekolah Dasar, 5(2), 63. https://doi.org/10.17509/mimbar-sd.v5i2.11444

Kurniaman, O., \& Noviana, E. (2017). Penerapan Kurikulum 2013 Dalam Meningkatkan Keterampilan, Sikap, Dan Pengetahuan. Primary: Jurnal Pendidikan Guru Sekolah Dasar, 6(2), 389. https://doi.org/10.33578/jpfkip.v6i2.4520

Kuswanto, J., \& Walusfa, Y. (2017). Pengembangan Multimedia Pembelajaran pada Mata Pelajaran Teknologi Informasi dan Komunikasi Kelas VIII. Innovative Journal of Curriculum and Educational Technology IJCET, 6(2), 58-64. https://doi.org/https://doi.org/10.15294/ijcet.v6i2.19335

Marwiyah, M., Rusijono, R., \& Arianto, F. (2019). The Development Of Cai Based Android In Solar System And Universe Topic For Tenth-Grade. Geosfera Indonesia, 4(2). https://doi.org/https://doi.org/10.19184/geosi.v4i2.9824

Nilasari, Djatmika, T., \& Santoso. (2016). Pengaruh Penggunaan Modul Pembelajaran Kontekstual terhadap Hasil Belajar Siswa Kelas V Sekolah Dasa. Jurnal Pendidikan: Teori, Penelitian, Dan Pengembangan, 7(1), 1399-1404. https://doi.org/https://doi.org/10.17977/jp.v1i7.6583

Nurfitriana. (2015). Pengembangan Permainan Monopoli Berbasis CAI Sebagai Media Pembelajaran Pada kompetensi Dasar Menganalisis Jabatan. Jurnal Pendidikan Administrasi Perkantoran, 7(4), 51-58. Retrieved from https://jurnalmahasiswa.unesa.ac.id/index.php/JPAPUNESA/article/view/30701

Prawitaningrum, A., \& Endarini, E. (2019). Efektivitas Model CIRC dan GGE Terhadap Kemampuan Berpikir Kreatif Matematika. International Journal of Elementary Education Universitas Pendidikan Ganesha, 3(3), 308-315. https://doi.org/http://dx.doi.org/10.23887/ijee.v3i3.19416

Purnamawati, Suardika, \& Manuaba. (2014). Pengaruh Penerapan Model Pembelajaran Kontekstual Berbasis Lingkungan terhadap Hasil Belajar IPA Siswa Kelas V SD di Gugus I Gusti Ngurah Rai Denpasar Selatan. Mimbar PGSD Undiksha, 2(1). https://doi.org/http://dx.doi.org/10.23887/jjpgsd.v2i1.3195

Purwani, F. (2015). Rancangan Perangkat Lunak Computer Assisted Instruction (CAI) Untuk Ilmu Tajwid Berbasis Web. WARDAH, 12(1). https://doi.org/https://doi.org/10.19109/wardah.v12i1.212 
Rahmawati, A. (2018). Identifikasi Masalah yang Dihadapi Guru dalam Penerapan Kurikulum 2013. Indonesian Journal of Primary Education, 2(1), 114-123. https://doi.org/https://doi.org/10.17509/ijpe.v2i1.14227

Rahmi, M. S. M., Budiman, M. A., \& Widyaningrum, A. (2019). Pengembangan Media Pembelajaran Interaktif Macromedia Flash 8 Pada Pembelajaran Tematik Tema Pengalamanku. International Journal Of Elementary Education, 3(2), 178-185. https://doi.org/10.23887/ijee.v3i2.18524

Sagala, G., Mesran, M., Sutiksno, D. U., Yuhandri, Y., \& Suginam, S. (2017). Perancangan Aplikasi Pembelajaran Pakaian Adat Asli Indonesia Berbasis Multimedia Dan Web Menerapkan Metode Computer Assisted Instruction (Cai). JURIKOM (Jurnal Riset Komputer), 4(4). https://doi.org/http://dx.doi.org/10.30865/jurikom.v4i4.711

Santoso, E. (2017). Penggunaan Model Pembelajaran Kontekstual Untuk Meningkatkan Kemampuan Pemahaman Matematika Siswa Sekolah Dasar. Jurnal Cakrawala Pendas, 3(1). https://doi.org/http://dx.doi.org/10.31949/jcp.v3i1.407

Siregar, Wardani, \& Hatika. (2017). Penerapan Pendekatan Pembelajaran Aktif Inovatif Kreatif Efektif Dan Menyenangkan (Paikem) Pada Pembelajaran Matematika Kelas Iv Sd Negeri 010 Rambah. Jurnal $\begin{array}{lllll}\text { Pemikiran Dan } & \text { Pengembangan }\end{array}$ https://doi.org/https://doi.org/10.22219/jp2sd.v5i2.4823

Tafonao, T. (2018). Peranan Media Pembelajaran Dalam Meningkatkan Minat Belajar Mahasiswa. Jurnal Komunikasi Pendidikan, 2(2), 1-13. https://doi.org/https://doi.org/10.32585/jkp.v2i2.113

Widodo, S., \& Kartikasari, K. (2017). Pembelajaran Pemecahan Masalah Matematis Siswa Sekolah Dasar Dengan Model Creative Problem Solving (Cps). Prisma, 6(1). https://doi.org/10.35194/jp.v6i1.28

Wulandari, Sudatha, \& Simamora. (2020). Pengembangan Pembelajaran Blended Pada Mata Kuliah Ahara Yoga Semester II di IHDN Denpasar. Jurnal Edutech Undiksha, 8(1), 1-15. https://doi.org/http://dx.doi.org/10.23887/jeu.v8i1.26459 